\title{
Francis Daniels Moore: one of the brightest minds in the surgical field.
}

\author{
Sara L. Low, BS \\ Thomas Jefferson University \\ Charles J. Yeo, MD \\ Thomas Jefferson University \\ Scott W. Cowan, MD \\ Thomas Jefferson University \\ Ashesh P. Shah, MD \\ Thomas Jefferson University
}

Follow this and additional works at: https://jdc.jefferson.edu/gibbonsocietyprofiles

Part of the History of Science, Technology, and Medicine Commons, and the Surgery Commons Let us know how access to this document benefits you

\section{Recommended Citation \\ Low, BS, Sara L.; Yeo, MD, Charles J.; Cowan, MD, Scott W.; and Shah, MD, Ashesh P., "Francis Daniels Moore: one of the brightest minds in the surgical field." (2015). Department of Surgery Gibbon Society Historical Profiles. Paper 27. \\ https://jdc.jefferson.edu/gibbonsocietyprofiles/27}

This Article is brought to you for free and open access by the Jefferson Digital Commons. The Jefferson Digital Commons is a service of Thomas Jefferson University's Center for Teaching and Learning (CTL). The Commons is a showcase for Jefferson books and journals, peer-reviewed scholarly publications, unique historical collections from the University archives, and teaching tools. The Jefferson Digital Commons allows researchers and interested readers anywhere in the world to learn about and keep up to date with Jefferson scholarship. This article has been accepted for inclusion in Department of Surgery Gibbon Society Historical Profiles by an authorized administrator of the Jefferson Digital Commons. For more information, please contact: JeffersonDigitalCommons@jefferson.edu. 


\section{Francis Daniels Moore: One of the Brightest Minds in the Surgical Field}

SARA L. LOW, B.S., CHARLES J. YEO, M.D., SCOTT W. COWAN, M.D., ASHESH P. SHAH, M.D.

From the Department of Surgery, Thomas Jefferson University, Jefferson Medical College, Philadelphia, Pennsylvania

Francis Daniels Moore was a pioneer ahead of his time who made numerous landmark contributions to the field of surgery, including the understanding of metabolic physiology during surgery, liver and kidney transplant, and the famous Study on Surgical Services of the United States (SOSSUS) report of $\mathbf{1 9 7 5}$ that served for decades as a guideline for development of surgical residencies. He was the epitome of what a physician should be, a compassionate and dedicated surgeon, innovative scientist, and a medical professional dedicated to quality medical education across all specialties.

$F$ RANCIS DANiels Moore (Fig. 1), also fondly known as "Franny," was born the youngest of three children on August 17, 1913, in Evanston, Illinois, to working class parents with New England roots. Exposure to the performing arts at a young age combined with a classical education, including Latin and frequent trips to Europe, groomed him into a cultured and well-rounded young man. These traits enabled him to flourish at Harvard College from 1931 to 1935. He graduated with a major in anthropology, completed premedical courses, and was president of both the Harvard Lampoon newsletter and Hasty Pudding theatrical club. ${ }^{1}$ He married Laura Benton Bartlett in 1935 and went on to obtain his M.D. degree cum laude from Harvard. ${ }^{2}$

Moore is arguably best known for his contributions to understanding the composition of bodily fluids and chemicals in relation to surgery. He completed his surgical residency at the Massachusetts General Hospital (MGH) and devoted his third postgraduate year to the study of radioisotopes at Huntington Hospital under the guidance of nuclear medicine pioneer, Dr. Joseph Aub. ${ }^{1}$ He eventually became a postgraduate National Research Fellow in isotope physics and its clinical application. ${ }^{2} \mathrm{He}$ returned to MGH and it was there that he began his unprecedented work on the metabolic response of the human body to surgery. ${ }^{2}$ The inspiration for this work can be traced back to the Cocoanut Grove Nightclub Fire on November 28, 1942. As a surgical resident, he was confronted by the arrival of 114 burn

Address correspondence and reprint requests to Scott W. Cowan, M.D., Assistant Professor of Surgery, 1025 Walnut Street, Suite 607, Philadelphia, PA 19107. E-mail: scott.cowan@jefferson.edu. victims and tasked with their care. The complexity of the body's response to burns and the unconventional yet successful treatment with petroleum jelly by his colleague, Dr. Oliver Cope, inspired Moore. Thereafter began the 5-year collaboration between Moore and Cope in Cope's biophysical research laboratory to explore physiologic changes caused by burns, which culminated in numerous seminal works on the subject. These studies became instrumental in revolutionizing the treatment and care of armed service casualties. ${ }^{1}$

The next chapter of Moore's professional life took place in the Peter Bent Brigham Hospital, now Brigham and Women's Hospital. He was appointed surgeon-inchief and the Moseley Professor of Surgery at Harvard Medical School on July 1, 1948, becoming the youngest chairman of surgery in Harvard history at the age of 34 years. $^{2}$ Brigham was a relatively new hospital, its surgeons more scholarly and more willing to think outside the box of conventional medicine. Moore preferred to describe himself as a scientistsurgeon, emphasizing the need for a deep connection between surgery and basic science. ${ }^{1}$ Using flame photometry, he pioneered studies on the normal fluid and electrolyte composition of the human body and their physiologic changes in response to various stimuli, including trauma and surgery. ${ }^{1,2}$ He published several books on this topic, the most famous being "The Metabolic Care of the Surgical Patient," published in 1959. This textbook became a must have for every surgeon of the era. His work indirectly enabled the establishment of modern intensive care units. ${ }^{2,3}$ Before Moore, surgeons aimed to perfect the anatomical correction of a disease, oblivious to subtle physiologic changes, frequently resulting in mortality. ${ }^{2} \mathrm{His}$ 


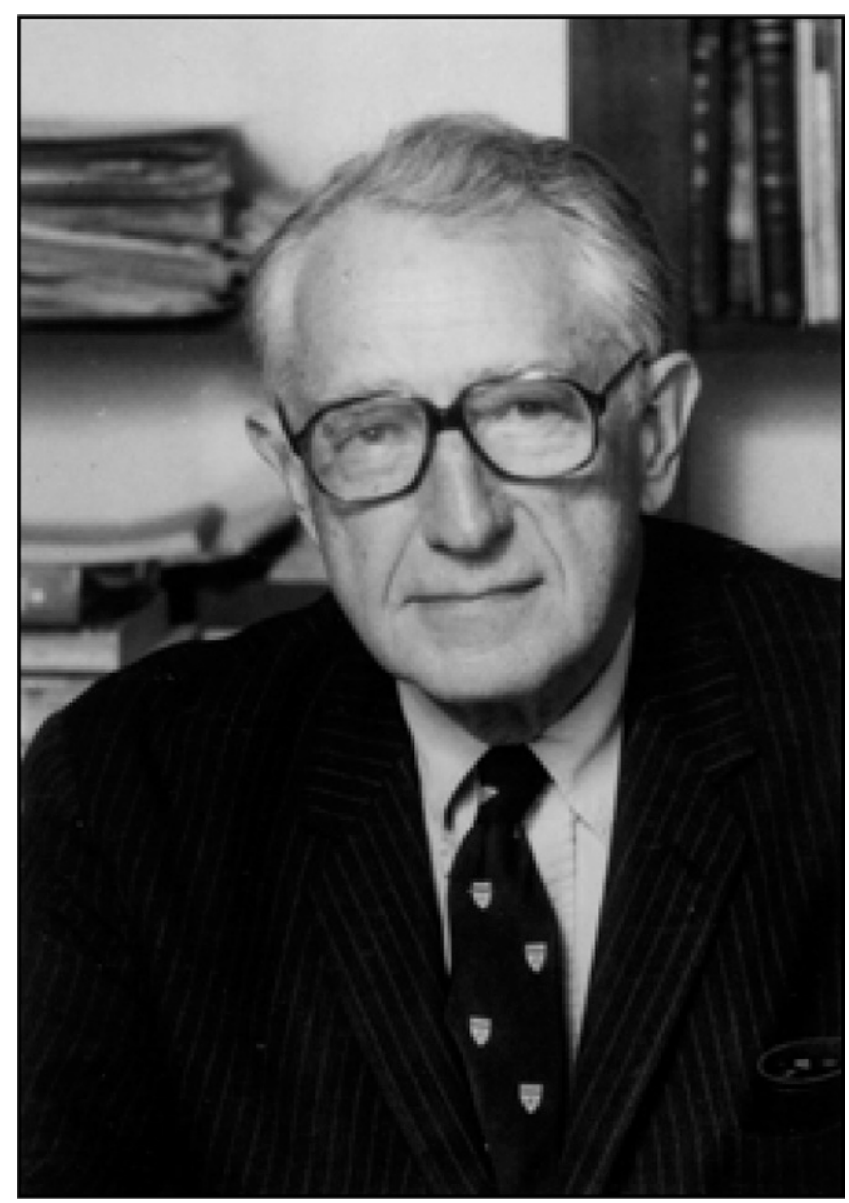

FIG. 1. Francis Daniels Moore.Starzl TE. Francis D. Moore. Proceedings of the American Philosophical Society. Biogr Mem 2005;149:605-13.

work directly contributed to reduced surgical morbidity because it enabled surgeons to detect signs of homeostatic instability pre- and postoperatively.

Moore also left his mark on the history of transplant surgery by spearheading the early trials at Brigham. His skill at identifying and molding talented minds resulted in the assembly of the transplant "dream team," consisting of Joseph Murray, George Thorn, David Hume, John Merrill, and Charles Hufnagel, thus igniting an exciting new era for transplant surgery at the Brigham. Despite early failures, Moore drove kidney transplant trials onward. In December 1954, Murray performed the first kidney transplant between the identical Herrick twins. ${ }^{2}$ Moore was also involved in one of the first liver transplants and early intracardiac surgery at the Brigham. ${ }^{2}$ Transplant surgery giants such as Murray and Starzl have paid tribute to Moore's influence on the development of organ transplantation, acknowledging that without him, transplant surgery may not be what it is today. ${ }^{1,4}$

In the mid-1960s, Moore's attention turned to issues of medical education and universal health care. In
1970, he chaired a joint committee formed by the American College of Surgeons and the American Surgical Association to carry out a nationwide study on the demographics, quality, economics, and education needs of the surgical profession. This study was named the Manpower Subcommittee of the Study on Surgical Services of the United States (SOSSUS). ${ }^{2}$ The 5 -year study produced a comprehensive report in $\mathrm{Au}$ gust 1975, including and detailing a huge database of the surgical profession and outlining a number of recommendations that served as guidelines for surgical residencies for the following decades: importance of board certification, restricting the number of surgical residencies, continuous medical education, and recertification. ${ }^{5}$

However, despite his numerous landmark contributions, it was his "soft skills" for which Moore is most fondly remembered. He placed great emphasis on communication, which is reflected in his autobiography on pages 123 to $124 .{ }^{1} \mathrm{He}$ is hailed as one of Harvard's most inspirational educators, skillfully delivering medical knowledge along with the importance of compassion and patient respect in the same breath. ${ }^{2}$ His residents loved him, although they were never sure if love was what they received in return. They received outstanding education, delivered by a stern yet understanding mentor, who was always empathetic and encouraging to those endeavoring to find their way forward. ${ }^{1-3}$ As many physicians put it, "If you really want to understand your own work (research), ask Franny to be your discussor," so thought-provoking were his observations.

Moore retired from the Brigham in 1976 but continued to be active in the American Philosophical Society (APS) and remained on the Harvard faculty as the Moseley professor emeritus. ${ }^{1,}{ }^{4}$ After Laura's death in 1988, he married Katharyn Watson Saltonstall in 1990. In 1995 he published his autobiography, "A Miracle and a Privilege: Recounting Half a Century of Surgical Advance." He wrote extensively about euthanasia as evidenced by these excerpts, "Injury and disease can so destroy that warm dwelling place that it is no longer habitable and the dweller... had best be permitted to depart." 1,2 Indeed on November 24, 2001, when sickness overcame him, he excused himself from the APS meeting, had breakfast with Mrs. Moore, dictated his last letters, and then died by his own hand. ${ }^{1}$

Perhaps the closest anyone ever came to capturing the essence of Francis Daniels Moore was his own son, who described his father as a fisherman, fishing for souls and minds that he could influence and nurture to make a difference in the world, especially in the management of the surgical patient. ${ }^{2}$ 


\section{REFERENCES}

1. Starzl TE. Francis D. Moore. Proceedings of the American Philosophical Society. Biogr Mem 2005;149:605-13.

2. Folkman J. Francis Daniels Moore: August 17, 1913November 24, 2001. Biogr Mem Natl Acad Sci 2006;88:268-82.

3. Brennan MF. Francis D. Moore. Ann Surg 2002;235:600-1.
4. Goode E. (November 29, 2001). Dr. Francis Moore, 88, dies; innovative leader in surgery. The New York Times. Available at: www.nytimes.com/2001/11/29/us/dr-francis-moore-88-diesinnovative-leader-in-surgery.html. Accessed: August 4th, 2013.

5. Moore FD. Report on the Manpower Subcommittee, Study on Surgical Services for the United States. Ann Surg 1975;182:526-30. 